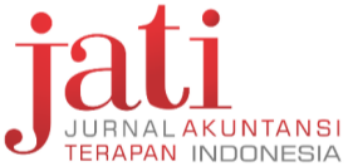

Jati: Jurnal Akuntansi Terapan Indonesia Vol 1 No 1 Hal 1-16 Maret 2018

\section{Praktik Pengelolaan dan Tata Kelola Pemerintahan Desa Dlingo di Kabupaten Bantul: Pembelajaran dari Desa Percontohan}

\author{
http://journal.umy.ac.id/index.php/jati \\ C)2018 JATI. All rights reserved \\ DOI: 10.18196/jati.010101
}

\section{DATA ARTIKEL:}

Diterima: 25 Feb 2018

Direviu: 07 Feb 2018

Direvisi: 16 Feb 2018

Disetujui: 17 Feb 2018

TOPIK ARTIKEL:

Akuntansi Sektor Publik

\begin{abstract}
ABSTRAK: Penelitian ini bertujuan untuk menginvestigasi dinamika permasalahan yang terjadi dalam pengelolaan dan tata kelola pemerintahan desa. Desa Dlingo dipilih sebagai obyek penelitian dikarenakan desa ini sudah menerima dana desa dan menghadapi berbagai permasalahan yang cukup kompleks dalam pengelolaan dan tata kelola pemerintah desanya, tetapi mampu untuk mengatasi berbagai permasalahan yang muncul tersebut. Pendekatan yang digunakan adalah investigatif dengan melibatkan informan penelitian dari aparatur desa, praktisi dan akademisi. Metode perolehan data adalah dengan teknik wawancara, dokmentasi dan observasi. Dari hasil studi ditemukan bahwa permasalahan yang terjadi dalam pelaksanaan pemerintahan desa dapat dibagi menjadi tiga sub utama, yakni meliputi: (1) masalah perumusan rencana strategis, (2) masalah pelaporan keuangan dan kinerja, dan (3) masalah pencapaian kinerja desa. Dalam rangka menyikapi permasalahan yang terjadi, Pemdes Dlingo melakukan sinergi dengan Pemkab, Pemprov, dan fihak universitas, serta melakukan pendekatan persuasive untuk merubah pola pikir masyarakat agar lebih mandiri.
\end{abstract}

Kata Kunci: Pemerintahan Desa; Pengelolaan; Tata Kelola; Permasalahan; Strategi Pemecahan

ABSTRACT: This study aims to investigate the dynamics of problems that occur in the management and governance practices of the village government. Dlingo Village Government was chosen as the object of study because this village has received village fund- ing and faced various complex problems in the management and governance, but able to overcome. The approach used is case study by involving several informants from the village employees, practitioners and academics. Methods of data acquisition is by interviewing, documentation and observation. This study reveals that the problems that occur in the implementation of village governance can be divided into three main sub-sectors, which are: (1) the problem of formulation of strategic plan, (2) the problem of financial reporting and performance, and (3) the problem of the achievement of village performance. In order to address the problems that occur, Dlingo Village Government synergize with Regency Government, Province Government, and the university, and also did persuasive approach to change the mindset of the community to be more autonomous.

Keywords: Village Governance; Management; Governance; Problems; Solution Strategy

\section{SITASI ARTIKEL:}

Sofyani, H., Suryanto, R., Wibowo, S.A., \& Widiastuti, H. (2018). Praktik Pengelolaan dan Tata Kelola Pemerintahan Desa Dlingo di Kabupaten Bantul: Pembelajaran dari Desa Percontohan. Jati: Jurnal Akuntansi Terapan Indonesia, 1(1), 1-16.

\section{PENDAHULUAN}

Tata kelola Desa di Indonesia berubah secara drastis semenjak diterbitkannya UU No. 6 tahun 2014 tentang desa, yang dalam penjelasannya menempatkan desa sebagai daerah otonom. Artinya adalah, dengan amanat yang ada pada UU tersebut, desa memiliki hak untuk mengatur dan mengurus urusan pemerintahan, kepentingan masyarakat setempat berdasarkan prakarsa masyarakat, hak asal usul, dan atau hak tradisional yang diakui dan dihormati dalam sistem pemerintahan Negara Kesatuan Republik Indonesia.

Dalam praktiknya, sebagai daerah otonom baru, Desa 
yang memenuhi persyaratan tertentu berhak menerima sejumlah uang sekitar satu milyar rupiah yang ditransfer dari dana Pemerintah Pusat (Pempus). Menyikapi pengesahan UU Desa oleh Dewan Perwakilan Rakyat Republik Indonesia (DPR RI), banyak kalangan yang khawatir hal tersebut bukannya mendatangkan keuntungan (advantage) dalam pembangunan desa, melainkan menjadi lahan baru terjadinya tindak pidana korupsi dan inefisiensi di level Desa. Untuk itu, maka penting bahwa di level Desa sekalipun perlu diberlakukan adanya sistem pengelolaan organisasi yang baik yang dikenal dengan istilah good governance (Jones dan Pendlebury, 2015; Mardiasmo, 2015; Ulum dan Sofyani, 2016). Usulan agar diselenggarakannya praktik good governance bertujuan untuk mengawasi dan menjamin agar dana desa yang nilainya cukup besar dapat dikelola dengan baik dan mampu mendatangkan nilai tambah (added value) dalam pembangunan desa secara khususnya dan Negara Indonesia secara umumnya.

Namun demikian, tidak sedikit akademisi dan politikus menilai bahwa implementasi praktik good governance di level Desa sulit dilakukan. Hal itu tidak lepas dari adanya anggapan bahwa sumber daya (khususnya manusia dan organisasi) yang ada di desa masih memiliki banyak keterbatasan. Selain itu, adanya peraturan-peraturan yang dinilai saling bertentangan, seperti permendes dan permendagri yang mengatur desa semakin membingungkan aparatur desa dalam menjalankan praktik good governance di level desa. Dari aspek teknis yang lain, desa juga mengalami hambatan dalam proses penyusunan pelaporan keuangan yang dipertanggungjawabkan kepada pemberi sumber dana desa, yakni Pemerintah Pusat (Pempus), Pemerintah Provinsi (Pemporv) dan Pemerintah Kabupaten (Pemkab). Pasalnya, masing-masing penyumbang dana desa tersebut memiliki aturan dan format pelaporan keuangan desa yang belum seragam. ${ }^{1}$ Berangkat dari permasalahan yang dipaparkan di atas, maka penting untuk dilakukan penelitian terkait praktik good governance di desa, khususnya menyangkut aspek-aspek apa saja yang menjadi penghambatnya, sehingga selanjutnya dapat dianalisis upaya atau strategi yang dapat ditempuh untuk menyikapi permasalahan-permasalahan terkait pelaksanaan praktik good governance di desa.

Sampai saat ini, studi terkait praktik good governance di desa relatif masih jarang dilakukan,

\footnotetext{
${ }^{1} \mathrm{Hal}-\mathrm{hal}$ yang dijelaskan pada paragraf ini bersumber dari wawancara pra-riset kepada anggota tim pendamping desa dan aparatur desa yang identitiasnya sengaja kami rahasiakan.
}

khususnya pasca reformasi dana desa yang dicirikan terbitnya UU No. 6 Tahun 2014. Penelitian yang ditemukan peneliti mengenai praktik pengelolaan dana desa pasca terbitnya UU No. 6 tahun 2014 diantaranya dilakukan oleh Amirullah, Ulum dan Prasetyo (2016) dan Utomo (2015). Amirullah, Ulum dan Prasetyo (2016) menemukan praktik akuntabilitas dan transparansi pelaporan keuangan desa Brambang Kidul tidak dijalankan sama sekali. Hal itu dikarenakan rendahnya tingkat pemahaman dan pengetahuan aparatur desa atas peraturan yang mengatur tugas dan wewenang yang harus dilakukan oleh aparatur desa. Akan tetapi, fenomena ini tidak dapat menjadi justifikasi untuk menyimpulkan bahwa tidak ada inisiatif dari aparatur desa untuk menjalankan praktik akuntabilitas yang baik dalam pemerintahan Desa. Hal itu karena praktik good governance yang tidak dijalankan oleh aparatur desa bisa saja terjadi karena adanya ketidakpastian peraturan Desa yang membuat bingung aparatur desa itu sendiri. Akhirnya, aparatur desa menjadi enggan melakukan pelaporan dana desa (Wijaya dan Akbar, 2013; Sofyani dan Akbar, 2013; 2015).

Sementara itu Utomo (2015) dalam penelitiannya mengenai Implementasi Kebijakan Anggaran Pendapatan dan Belanja Desa Untuk Meningkatkan Pembangunan Desa menunjukkan bahwa dalam proses penyusunan APBDes sering mengalami keterlambatan, hal ini dikarenakan karena sumber daya yang dimiliki desa masih sangat rendah, dan belum maksimalnya sosialisasi dan pelatihan penyusunan APBDes oleh Pemerintah Kabupaten selaku supervisor dari pemerintah Desa. Dari sisi pelaksanakan program pembangunan yang tertuang dalam Rencana Kerja Pemerintah Desa (RKPDes), dari tujuh program kerja yang direncanakan hanya empat program yang terlaksana. Hal ini disebabkan karena pemerintah desa dalam pengelolaan pembangunan dan anggaran kurang transparan sehingga masyarakat tidak pernah tahu program pembangunan pemerintah desa dan anggaran yang menyertainya. Selanjutnya, mekanisme pengawasan yang tujuan untuk mengawal pemerintahan desa tidak berjalan dengan baik.

Berangkat dari masih sedikitnya referensi riset yang membahas mengenai pengelolaan dan praktik tata kelola pemerintah desa, sementara isu ini masih merupakan topik hangat untuk diteliti, maka penelitian ini bertujuan untuk mengeksplorasi pengelolaan dana desa pada Pemerintah Desa Dlingo di Kabupaten Bantul. Dipilihnya desa ini sebagai lokasi penelitian adalah dikarenakan desa ini sudah menerima dana desa dan menghadapi berbagai permasalahan yang cukup kompleks dalam pengelolaan dan tata kelola pemerintah 
desanya, tetapi mampu untuk mengatasi berbagai permasalahan yang muncul tersebut. Berbeda dengan peneltian Utomo (2015) dan Amirullah, Ulum dan Prasetyo (2016), penelitian ini dilakukan secara lebih mendalam dengan pendekatan studi kasus menggunakan teknik wawancara kepada informan dari aparatur desa dan pakar praktisi sekaligus akademisi, serta mengombinasikannya dengan dokumentasi dan observasi pada praktik good governance di desa (lihat juga: Riyanto, 2015).

Hasil penelitian ini memberikan temuan dan rekomendasi praktis yang lebih komprehensif dari penelitian sebelumnya (Utomo, 2015; Amirullah, Ulum \& Prasetyo, 2016) kepada para praktisi di desa dan pembuat regulasi dana desa, yakni sebagai bahan pertimbangan dalam melakukan perbaikan dan perumusan kebijakan terkait praktik good governance bagi pemerintahan desa. Hasil penelitian ini juga memberikan kontribusi teoritis, khususnya sebagai tambahan kajian literatur pada konsep good governance yang secara khusus mengkajinya di level organisasi desa yang notabene masih sangat terbatas.

Susunan paper ini diawali dari pendahuluan yang memaparkan urgensi dari pentingnya penelitian ini dilaukan. Selanjutnya penjelasan mengenai metode penelitian, lalu bagian hasil dan pembahasan. Paper ini ditutup dengan simpulan.

\section{METODE PENELITIAN}

Jenis penelitian ini adalah penelitian kualitatif dengan pendekatan studi kasus. Pelaksanaan penelitian di lapangan didesain untuk melakukan investigasi terkait permasalahan yang muncul dalam implementasi pengelolaan (management) dan praktik tata kelola (governance) pemerintah desa. Selain itu, peneliti juga akan melakukan eksplorasi pada aspek perencanaan strategik, akuntabilitas, dan kinerja desa, baik kinerja dari segi pelaksanaan pemerintahan maupun kinerja dalam rangka menyikapi berbagai permasalahan yang dihadapi desa. Desain kerangka konseptual penelitian ini ditampilkan pada Gambar 1.

Obyek dari penelitian ini adalah desa Dlingo yang terletak di sisi tenggara paling ujung kabupaten Bantul dan langsung berbatasan dengan kabupaten Gunung Kidul, wilayah bagian dari Daerah Istimewa Yogyakarta. Dipilihnya desa ini sebagai objek penelitian karena desa Dlingo merupakan desa yang sebelumnya dipandang terpencil dan tertinggal, namun dalam kurun waktu sekitar empat tahun (2012-sekarang), desa ini mengalami perkembangan yang sangat pesat dan berhasil menyandang gelar desa percontohan untuk penge- lolaan desa dan dana desa bagi desa-desa lain di seluruh Indonesia. Hal ini dapat dilihat dari banyaknya desa-desa dari penjuru Indonesia yang datang untuk studi banding ke desa Dlingo, yakni dari desa di pulau Jawa, Sulawesi, dan Sumatera. Selain itu, sembilan aspek prinsip tata kelola yang meliputi: participation, rule of law, transparancy, responsiveness, consensus orientation, equity, effectiveness and efficiency, accountability, strategic vision sudah terpenuhi dengan baik.

Informan utama dari riset ini adalah pemerintah Desa, yakni Lurah Desa (Kepala Desa) Dlingo dan Bagian Pembangunan Sarana dan Prasarana (Sarpras). Selain itu, informan dari desa juga diambil dari kepala dusun (Kadus) dan beberapa masyarakat yang juga berperan dalam pembangunan desa, untuk dimintai informasi yang bersifat pendukung dan konfirmatif. Penggunaan informan dari dua sisi, yakni sisi manajemen (Kades dan Sarpras) selaku steward dan Kadus dan masyarakat selaku pemangku kepentingan (public-stakeholder) dilakukan dengan alasan agar data penelitian yang didapat memiliki keseimbangan perspektif, mengingat data utama dari penelitian ini adalah dari hasil wawancara. Hal ini guna menghindari terjadinya bias normatif pada hasil penelitian, yakni simpulan penelitian yang hanya berdasar pada satu sisi perspektif informan. Selain itu, untuk menggali permasalahan dan solusi sementara yang dapat dijalankan terkait pengelolaan desa dan keuangan desa serta pelaporan akuntabilitas keuangan desa, maka dilakukan wawancara dengan pakar praktisi sekaligus akademisi dari salah satu Universitas di Yogyakarta.

Data pada penelitian ini adalah data primer, yaitu hasil wawancara yang diperoleh dari para informan penelitian dan hasil dokumentsi serta observasi lapangan terkait laporan keuangan desa dan luaran dari pembangunan fisik dan non-fisik di desa. Sumber data penelitian untuk wawancara berasal dari para informan yang telah disebutkan di atas. Sedangkan sumber data untuk dokumentasi adalah dokumen-dokumen yang berkaitan dengan perencanaan strategis dan akuntabilitas pemerintah desa Dlingo. Untuk sumber data observasi adalah seluruh seluk-beluk desa Dlingo, khususnya yang meliputi luaran dari pembangunan baik fisik maupun non fisik.

Teknik analis data menggunakan pendekatan kualitatif. Untuk teknik wawancara yang dipakai adalah wawancara semi-terstruktur dan terbuka, sambil merekamnya dengan audio recorder, lalu mentranskripnya (Creswell, 2010). Analisis data dilakukan dengan pendekatan analisis tematik deduktif yang menurut Braun dan Clarke (2006) merupakan 


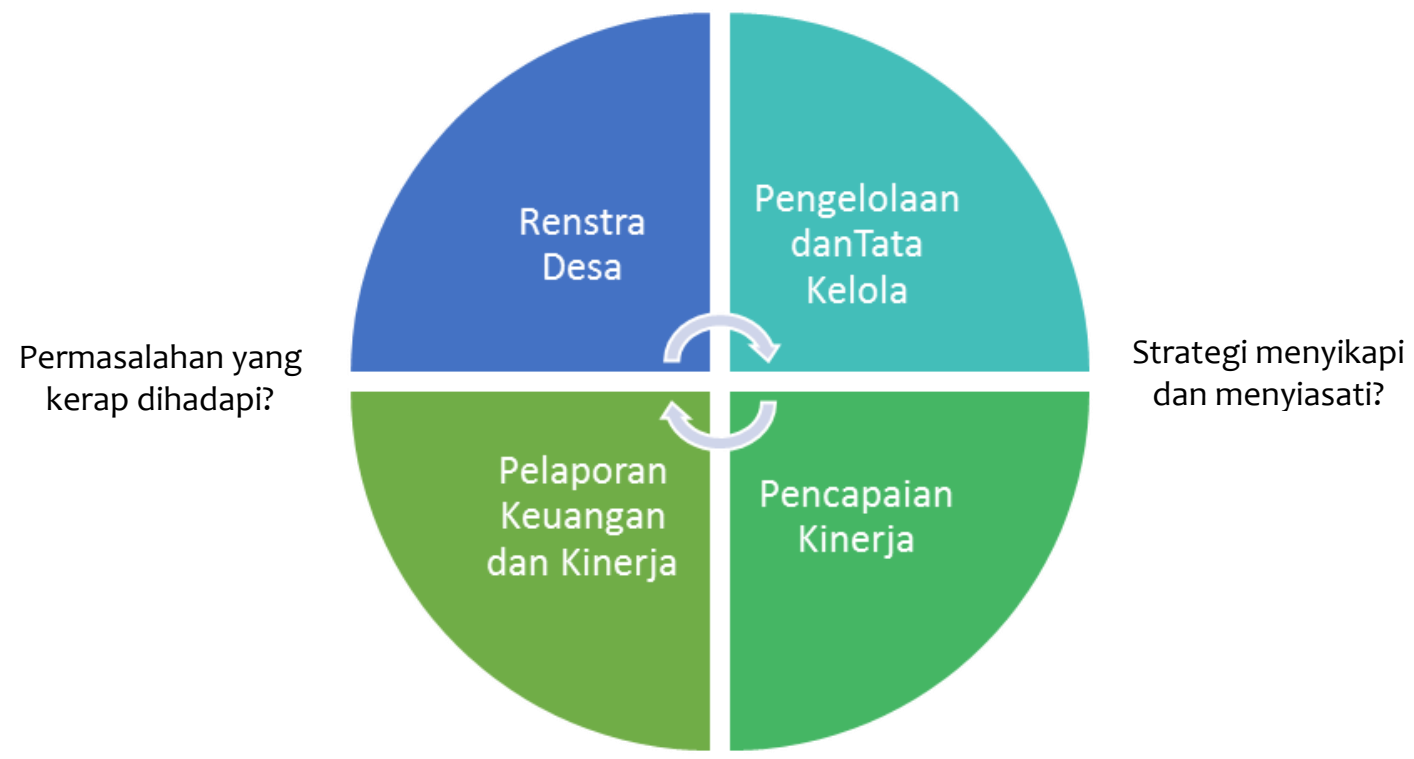

Gambar 1. Desain Kerangka Konseptual Penelitian

metoda analitik dalam rangka menganalisis data kualitatif dengan tahapana identifikasi, analisis dan melaporkan pola atau tema yang terdapat didalam data. Analisis tematik sendiri merupakan salah satu klasifikasi dari teknik analisis isi (content analysis).

Langkah-langkah yang ditempuh meliputi melakukan coding, mengelompokkan dalam kategori-kategori, menemukan ide utama dan mengelompokkannya ke dalam tema-tema, selanjutnya menemukan pola umum dari kecenderungan yang berhasil ditemukan dari data (Sofyani dan Akbar, 2015). Dalam analisis tematik peneliti tidak diperlukan penjelasan rinci yang terstruktur tentang kerangka teori dan pendekatan yang digunakan oleh responden dalam memaparkan pendapatnya (Wijaya dan Akbar, 2013). Peneliti hanya akan menangkap persepsi bebas dari responden sebagai suatu data yang dapat dimaknai sebagai pengalaman realitas terkait pelaksanaan SPK. Akan tetapi penyandaran secara jelas fenomena yang digali dengan posisi teori tertentu penting untuk dilakukan (Braun dan Clarke, 2006).

Sedangkan data yang berasal dari dokumentasi dan observasi diperoleh dengan mendokumentasikan situs penelitian berupa benda fisik maupun non-fisik dari luaran program/kegiatan desa. Data hasil dokumentasi dan observasi ini akan digunakan sebagai bukti pendukung atau pembantah dari hasil analisis wawancara. Hal inilah yang menjadi alasa peneliti memasukkan data dari dokumentasi dan observasi agar validitas dan kredibilitas hasil riset dapat dipertanggungjawabkan.
Pengujian pada realibilitas dan validitas dari data wawancara yang sudah terkumpul dilakukan dengan prosedur sebagai berikut; petama, dalam rangka memastikan validitas data, maka dilakukan pemeriksaan kembali hasil transkrip. Aktivitas ini bertujuan untuk memastikan tidak adanya kesalahan yang dibuat selama proses transkripsi. Kedua, untuk memastikan reliabilitas data, maka perlu melakukan tanya-jawab dengan sesama rekan peneliti (peer de-briefing) untuk meningkatkan keakuratan hasil penelitian (Creswell, 2010).

\section{HASIL DAN PEMBAHASAN ${ }^{2}$}

Sebelum dipaparkan hasil penelitian, berikut disajikan Tabel 1 yang berisi data informan beserta kodifikasi agar memudahkan dalam membaca hasil penelitian ini. Dari deskripsi responden pada Tabel 1, dapat disimak bahwa pendidikan tertinggi dari apaprtur Desa adalah Diploma. Sementara kepala desa sendiri memiliki pendidikan SMA. Namun demikian, dengan segala keterbatasannya, pemerintah Desa Dlingo dapat memajukan desanya dengan sangat pesat. Hal inilah yang menjadi isu menarik untuk dikaji. Secara tidak langsung, Desa Dlingo menunjukkan fenoemena dimana tingkat pendidikan bukan menjadi masalah untuk menjadi Desa yang maju dan berdaya saing.

\footnotetext{
${ }^{2}$ Nama Informan sengaja di-anonim-kan sesuai kesepakatan pra-wawancara. Ket: IAI (Ikatan Akuntan Indonesia); FDASP (Forum Dosen Akuntansi Sektor Publik); PwC (Pricewaterhouse Coopers).
} 
Tabel 1. Deskripsi dan Kodifikasi Informan Penelitian

\begin{tabular}{cccccc}
\hline No. & Dusun & Pendidikan & Posisi & Status & Kode \\
\hline 1. & Dlingo 1 & SMA & Lurah/Kades & Informan Utama & LD \\
2. & Pakis 1 & SMP & Kadus & Informan Pendukung & PKS1 \\
3. & Pakis 2 & SMA & Kadus & Informan Pendukung & PKS2 \\
4. & Pokoh 1 & Diploma & Sarpras & Informan Utama & SP \\
5. & Pokoh 2 & SMA & Kadus & Informan Pendukung & PKH2 \\
6. & Kebosungu 1 & SMA & Kadus & Informan Pendukung & KBS1 \\
7. & Kebosungu 2 & SMA & Kadus & Informan Pendukung & KBS2 \\
\multicolumn{7}{c}{ 8. } & Ahli & S2/Master of & Dosen, & Anggota IAI, & Informan Utama \\
& Accounting & Konsultan Desa, & & \\
\end{tabular}

\section{Profil Desa Dlingo}

Dlingo berasal dari kata Delengo (lihatlah) hal ini terjadi disaat $\mathrm{Ki}$ ageng Perwito Sidiq mengungkap adanya tumurunnya Ratu Kencono di sebuah bukit Gunung Pasar melalui sebuah Bokor Kencono di Desa Krendetan, Delanggu. Hal ini didasari lelaku ki Ageng Giring III untuk meraih kamulyan dengan menggiring wahyu keprabon dari Majapahit (Malang). Desa Dlingo yang pada mulanya merupakan daerah inclave Imogiri yang menginduk ke kasunanan Surakarta. Menurut Undang-undang Darurat nomor 5 tahun 1957 daerah enclave Imogiri (Surakarta) dan Kotagede (Surakarta) telah dimasukkan kedalam wilayah Daerah Istimewa Yogyakarta. Berdasarkan Surat Keputusan DPR DIY Nomor 18/K/DPR/1955 dan dituangkan dalam PERDA DIY Nomor 1 tahun 1958 tentang Perubahan Batas-batas dan nama kapanewon-kapanewon Imogiri, Gondowulung dan Kotagede dalam Kabupaten Bantul. Dalam rangka menambah kelancaran dan efisiensi pemerintahan Lima kapanewon (Imogiri (ska), Imogiri (Yk), Kotagede (ska), Kotagede (yk), Gondowulung tersebut dijadikan empat kapanewon yakni Imogiri, Dlingo, Banguntapan, Pleret.

Kapanewon Dlingo terdiri dari 6 Desa yakni Dlingo, mangunan, Temuwuh, Muntuk (Imogiri ska) dan Terong, Jatimulyo (kotagede ska). Didalam mengadakan perubahan batas kapanewon-kapanewon tersebut batas-batas desa tidak terjadi perubahan, dan ditentukan Ibu kota Kapanewon/ kecamatan untuk perkembangan daerah dikemudian hari dalam lapangan pemerintah, ekonomi, social dan lain sebagainya. Biarpun tempat Ibu Kota telah ditentukan dalam Peraturan Daerah ini, tetapi Dewan Pemerintah Daerah Istimewa Yogyakarta perlu diberi kekuasaan untuk menunjuk tempat Ibu Kota sementara yang lain, jika faktor-faktor mengenai kepentingan pemerintahan memerlukan tindakan ini, atau hal itu perlu dilakukan dalam keadaan darurat, umpamanya gangguan keamanan, bahaya alam dan sebagainya. Sehingga Dlingo masih beribukota di Imogiri Ska (dlingobantul.desa.id, 2016).

Desa Dlingo memiliki 10 Dusun (daerah satu level di bawah desa). Sejak 2013 Desa Dlingo menjadi desa percontohan dalam hal tata kelola. Desa Dlingo juga menjadi desa melek Teknologi Informasi ( $\mathrm{TI}$ ) yang ditandai dengan adanya website desa di http://dlingo-bantul.desa.id/index.php/first. Dalam kurun waktu sekitar empat tahun (2012sekarang) desa Dlingo telah mengalami berbagai kemajuan yang dapat dilihat dari struktur organisasi desa yang semkain lengkap, system pelayanan yang cepat dan tepat, serta tingkat kepuasan penduduk pada pemerintah desa yang meningkat. Selain itu, berbagai potensi desa juga terus ditingkatkan, seperti kerajinan, wisata, kuliner, dan budaya. Dari berbagai kemajuan itulah kemudian pemerintah pusat melalui Kementrian Dalam Negeri menjadikan desa Dlingo sebagai tempat studi bagi desa-desa lain di Indonesia dalam hal tata kelola pemerintahan desa.

Dari observasi, doumentasi dan wawancara yang dilakukan kepada berbagai fihak, peneliti merumuskan permasalahan yang terjadi dalam pengelolaan dan praktik tata kelola pemerintah Desa Dlingo Kabupaten Bantul Daerah Istimewa Yogyakarta, sebagai berikut:

\section{Masalah Teknis Merumuskan Renstra}

Kendala utama dari pengelolaan desa adalah penyusunan renstra desa (\#LD dan AP). Hal ini sulit dilakukan secara baik dan benar oleh aparatur desa. Hal ini sangat wajar terjadi karena pemurumsan rencana strategis, meliputi: perumusan visi misi, tujuan, capaian dan target, program dan kegiatan, anggaran dan target anggaran adalah hal yang tidak mudah. Apalagi mayoritas aparatur desa secara akdemik rata-rata maksimal menempuh pendidikan 
Sekolah Menengah Atas. Akibtanya, seringkali ditemukan, renstra desa hanya menjadi "pemanis" atau semboyan tanpa makna", khususnya di daerah Bantul sebelum adanya bantuan dari para ahli dalam pengelolaan desa. Selain itu, tata kelola dalam aspek perencanaan juga tidak berjalan baik, yakni tidak memberlakukan prinsip partisipatif. Hal ini dikarenakan pola pikir masyarakat desa yang menganggap tugas pengelolaan desa sepenuhnya adalah oleh dan tanggungjawab pemerintah desa. Akhirnya, program yang muncul dari suatu desa lebih bersifat ketetapan dari pemerintah desa atau ketika pemerintah desa tidak memiliki inisiasi program, program biasanya berdasarkan arahan pemerintah kabupaten yang sebenarnya belum tentu mengetahui secara detail ikhwal desa yang diarahkan. Berikut petikan wawancara dengan salah satu informan AA dan LD:

\begin{abstract}
“Kesulitan dalam membuat perencanaan, karena membuat konsep perencanaan ini termasuk perencanaan strategis, dia harus melihat potensi desa, dia harus melihat prioritas kebutuhan. Nah disini biasanya kemampuan atau kapasitas perangkat desa untuk membuat perencanaan strategis memang terbatas. Sehingga pada akhirnya program-program yang ada itu ditentukan oleh kabupaten. Yang mana harusnya di desa itu memiliki semangat partisipatif ternyata tidak jalan."\#AP3
\end{abstract}

\section{Akar dari Masalah Perencanaan Strategis}

Masalah Keterbatasan Kapabilitas Sumber Daya Manusia. Masalah perumusan renstra tidak lepas dari kapabilitas sumber daya manusia (SDM) aparatur desa, baik di pemerintah desa maupun di dusun (organisasi yang dibawahi desa). Hasil ini juga sejalan dengan temuan Subroto (2009), Utomo (2015), dan Amirullah, Ulum dan Prasetyo (2016). Hal ini pula yang dihadapi oleh desa Dlingo ketika awal mula Desa ini diberikan amanah dana desa dari Pempus. Para Kadus yang dilibatkan dalam partisipasi perumusan renstra desa belum memiliki pengetahuan yang cukup luas untuk merumuskan visi dan misi desa yang diturunkan ke Dusun ${ }^{4}$.

\footnotetext{
3 Tanda \# pada paper menjelaskan bahwa argumentasi yang dipaparkan berasal dari hasil wawancara kepada informan yang inisialnya ditampilkan.

${ }^{4}$ Unit yang berada satu level di bawah Desa. Desa merupakan Kelurahan yang dipimpin oleh Lurah Desa yang membawahi beberapa Dusun.
}

Berikut kutipan wawancara dari salah satu dari Kadus Kebosungu 1:

"Kita itu masih belum faham mengenai
pengelolaan dusun sebagaimana yang
dikehendaki pak Lurah. Ini karena kami
sendiri memiliki keterbatasan pemahaman
untuk mencari ide kreatif untuk mewu-
judkan misi Lurah, yakni satu dusun satu
produk kreatif." \#KBS1

Miskin Data. Menurut Informan dari Konsultan Desa (\#AP), akar masalah dari sulitnya untuk merumuskan rencatan stratgis adalah desa sangat miskin data, sementara untuk mengukur potensi, keunggulan, dan kelemahan desa, diperlukan data yang valid dan uptodate. Sayangnya, data ini tidak dimiliki desa, dan ketika data diminta ke pemerintah kabupaten yang menaungi desa, data yang ada tidak valid dan tidak optodate (\#AP dan LD). Hal ini tentu menjadi masalah untuk menentukan program yang tepat untuk dicanangkan oleh pemerintah desa.

\begin{abstract}
"Sebenarnya akar permasalahan ini di desa, yaitu maksudnya miskin data. Desa sebagai pengumpul namun ironisnya malah desa tersebut tidak memiliki data, dan ironisnya lagi ketika desa ini meminta data ke dinas atau PEMDA itu sulit, kalaupun tidak sulit ya datanya lama. Sehingga tanpa adanya data perencanaan ini hanya berada di anganangan saja. Sehingga dengan data yang minim kita sulit mengidentifikasi mana yang skala prioritas."\#AP
\end{abstract}

Kekeliruan Pola Pikir dan Keengganan Untuk Berpartisipasi Membangun Desa. Permsalahan yang umum ditemui di desa adalah pola pikir masyarakat yang menunggu bantuan dari pemerintah, baik kabupaten, provinsi, maupun pusat. Mayoritas masyarakat desa beranggapan bahwa rakyat desa harus dibantu karena mereka adalah rakyat kecil dan lemah dari sisi ekonomi (\#LD). Padahal, manusia dimanapun berada memiliki potensi yang akan berkembang jika terus diasah. Pola berfikir seperti yang dijelaskan di atas akhirnya menjadikan masyarakat desa enggan dan malas untuk terlibat (berpartisipasi) dalam membangun desa, dan hanya menunggu mendapatkan bantuan dari pemerintah desa.

\footnotetext{
"Masyarakat di desa mayoritas mereka adalah oyek, bukan subyek pembangunan. Dampaknya adalah mereka menunggu
} 
orang lain membangun desa yang mereka tempati, padahal semestinya merekalah yang membangun desa mereka, karena desa mereka adalah rumah mereka..."\#LD

\section{Paradigma Bahwa Pembangunan Adalah Fisik}

Desa. Menurut pemerintah desa (\#LD dan SP) permasalahan lain yang muncul saat perumusan rencana strategis adalah paradigma masyarakat terkait pembangunan yang masih berfokus pada hanya pembangunan fisik, dan belum memiliki tingkat kesadaran yang mapan dalam hal pembangunan non-fisik, seperti: pemberdayaan lembaga dan masyarakat, pemanfaatan sarana yang bersumber dari bantuan pemerintah kabupaten, provinsi dan pemerintah pusat, pelatihan dan pendampingan, serta penyuluhan perilaku hidup sehat dan mandiri. Kondisi tersebut memicu banyaknya program kerja yang diusulkan masyarakat didominasi oleh program pembangunan saja. Padahal pemerintah desa menginginkan adanya keseimbangan antara pembangunan fisik dan non fisik.

Munculnya fenomena yang dipaparkan di atas menurut pemerintah desa (\#LD) dikarenakan masyarakat masih belum memiliki visi dari desa mereka sendiri. Akhirnya, perencanaan yang disusun adalah aktivitas yang bersifat reaksi dari suatu kondisi yang tidak diingini, dan bukan berupa aksi yang berdasar pada perencanaan stratgis. Sebagai contoh, ketika masyarakat menemukan adanya jalan yang rusak, masyarakat akan menyusun program perbaikan jalan, tetapi tidak meganalisis tujuan, kegunaan dan manfaat dari perbaikan jalan tersebut. Padahal, bisa saja jalan yang rusak tersebut tidak memiliki fungsi lagi.

“...sudut pandang masyarakat yang masih memandang bahwa pembangunan itu berupa fisik. Jadi untuk pemberdayaan mereka belum ahli... Dan biasanya setiap usulan itu berupa (permintaan, pen) bantuan modal." \#LD

Masalah Pendampingan Desa. Masalah berikutnya yang dihadapi desa adalah terkait pendampingan. Fakta di lapangan, ternyata tidak semua desa memiliki pendamping desa yang membantu dalam pengelolaan dan mengatur praktik tata kelola desa. Selain itu, fokus pembantuan dari pendampin desa juga terbatas pada aspek administratif dan pertanggungjawaban keuangan saja. Padahal, pertanggungjawaban (akuntabilitas) hanya satu dari elemen pengelolaan desa yang meliputi: perencanaan strategis, perencanaan program dan penganggaran, pelaksanaan, dan evaluasi serta pelaporan (\#AP). Selain pendamping desa hanya berfokus pada kepatuhan pertanggungjawaban saja, masalah lainnya adalah jumlah pendamping desa juga relatif sedikit dibandingkan desa yang semestinya didampingi (\#AP). Hal ini berimbas pada harapan dari akselarasi desa untuk mandiri menjadi terhambat. Berikut petikan wawancara dengan salah satu informan Konsultan Desa:

“....ya, pertama tidak semua desa mempunyai pendamping. Yang kedua pada level teknis pendamping juga masih berfokus ke pertanggungjawaban, jadi lebih ke aspek administratif pertanggungjawaban. Tapi nilai dari Undang-Undang desa yang memberikan otonomi yang luas bagi desa untuk mengatur potensinya supaya menjadi desa mandiri itu masih jauh. Jadi harapannya dengan dikasih dana dapat terjadinya akselerasi, tapi sekarang Kenyataanya orang ini hanya berfokus pada kelengkapan administrasi. \#AP

Masalah Praktik Kejar Tayang. Permasalahan menarik dari pengelolaan desa berikutnya adalah "praktik kejar tayang". Maksudnya adalah, jika diamati di lapangan, pengelolaan desa dan penggunaan dana desa seperti praktik "yang penting program jalan". Hal ini tentu berimbas negative, yakni berkaitan dengan permasalahan cita-cita akselarasi desa untuk semakin mandiri menjadi terhambat. Pasalnya, implementasi pengelolaan desa masih berfokus pada kepatuhan aturan. Akhirnya, hal ini menjadikan pergerakan desa hanya sebatas untuk mencairkan uang dana desa, dan lalu melaporkannya. Persoalan apakah pengelolaan desa berjalan sesuai cita-cita dari kebijakan dana desa itu sendiri seolah tidak terperhatikan (\#AP). Dari kacamata teori isomorfisma institusional, hal ini jelas mengindikasikan bahwa pelaksanaan UndangUndang desa di banyak desa masih sebatas koersif (Gudono, 2014; Sofyani dan Akbar, 2015). Namun demikian, hal ini masih dinilai wajar, mengingat kebijakan dana desa yang diatur dalam UndangUndang desa ini merupakan kebijakan yang masih sangat baru, dan masih dalam fase transisi. Sehingga, sock yang terjadi oleh pelaksana kebijakan baru merupakan keniscayaan (Cavalluzzo dan Ittner, 2004; Sofyani dan Akbar, 2013). Akan tetapi, hal ini perlu menjadi perhatian agar segera dapat diatasi. Berikut petikan wawancara dengan salah satu informan PR: 
"Tuntutan peraturan, jadi mereka belum berfikir apa sih di desa yang masih perlu dibutuhkan. Jadi ibaratnya sisitem hanya seperti kejar tayang. Sementara nilai pemberdayaan ini (desa, pen) belum kelihatan, dan pendamping desa juga masih fokus di aspek kepatuhan. Baik berupa formatnya, kelengkapan dan sebagainya."

\section{Masalahan dalam Pelaporan (Akuntabilitas) Keuangan dan Kinerja Desa}

Benturan Peraturan dan Belum adanya Standar Pelaporan. Dari analisis wawancara dengan aparatur Desa (\#LD dan SP) dan observasi di Desa Dlingo, peneliti menemukan permasalahan dalam pelaporan, baik keuangan maupun kinerja, dikarenakan adanya beberapa perubahan peraturan yang mendadak terkait akuntabilitas desa. Padahal, dana desa bersumber dari tiga sumber utama, yakni Pempus, Pemprov, dan Pemkab. Itu artinya, pelaporan keuangan harus dapat terintegrasi menjadi satu dan tidak seperti pada kasus-kasus yang telah lalu dimana pelaporan keuangan desa menjadi tiga versi yang disesuaikan dengan pemberi dana desa. Permasalahan pelaporan ini dirasakan aparatur desa karena implementasi Undang-Undang desa dapat dikatakan masih dalam fase transisi, sehingga masih ada tumpah tindih antara Peraturan Kementerian Dalam Negeri (Permendagri) dan Peraturan Kementrian Desa (Permedes). Kebingungan menyikapi tumpang tindih dan pro-kontra peraturan pengelolaan dan tata kelola desa ini juga menjadi salah satu penggangu kinerja desa karena keluarnya peraturan desa tersebut terjadi di pertengahan program desa yang sedang berjalan (\#LD dan SP).

“...kemarin di awal tahun 2015 itu kita bingung harus pakai acuan yang mana untuk formula pelaporan dan lain sebagainya, tapi alhamdulillah di awal-awal tahun ini.."\#SP

Selain itu, masih banyak desa yang belum mendapatkan alat bantu untuk pelaporan, yaitu software akuntansi desa ${ }^{5}$ (\#LD dan SP). Walaupun beberapa desa sudah diberikan (termasuk Dlingo), hingga penelitian ini dilakukan, belum ada pendampingan secara memadai dilakukan oleh pendamping desa dari BPKP untuk operasional software

\footnotetext{
${ }^{5}$ Di beberapa desa d Bantul sudah mulai diadakan, trmasuk di Desa Dlingo, yakni Sistem Informasi Keuangan Desa (Sikeudes) dari Badan Pengawas Keuangdan dan Pembangunan (BPKP).
}

akuntansi (\#AP). Berikut petikan wawancara dengan salah satu informan LD dan AP:

"Desa itu memiliki karakteristik yang kompleks, karena desa menerima tiga sumber dana. Dari APBN yang itu milik desa, dari APBD yaitu ADD dan yang ketika dari desa sendiri PADes. Artinya, hal ini tidak simpel karena tiga sumber dana ini harus dikelola nanti digabung menjadi satu atau dapat dijadikan secara terpisah-pisah. Artinya disini memang dibutuhkan alat bantu. Sebenarnya dari pemerintah sudah ada software namun di BPKP tidak ada pendamping yang cukup, sehingga ada software namun tidak ada yang mengajarinya. Karena kalau ini menjadi manual ini akan menjadi sulit..." (\#AP)

"Kalau Dlingo sudah ada pelatihan BPKP dan software sudah diinstal di komputer desa. Hanya memang pelatihan sendiri masih dirasa kurang... Untuk Desa lain sepertinya ada yang belum dapat pelatihan itu."\#LD

\section{Permasalahan Pencapaian Kinerja Desa}

Selain menghadapi masalah perumusan renstra dan akuntabilitas, desa juga menghadapi masalah besar lainnya, yakni upaya untuk mencapai kinerja yang telah dirumuskan dalam program kerja tahunan desa. Terdapat beberapa kendala atau permasalahan yang dihadapi Pemdes Dlingo, diantaranya;

Kurangnya Kontrol atas Program Kerja yang Didelegasikan ke Kepala Dusun. Dalam menyelenggarakan pembangunan desa, Pemdes Desa Dlingo mendisposisikannya ke Kadus untuk beberapa program tertentu. Masalah yang pernah dihadapi Desa Dlingo adalah adanya Kadus yang tidak mengerjakan tugasnya dengan baik. Di sisi lain, kontrol (pengendalian dan pengawasan) dari desa waktu itu masih lemah. Akhirnya, terdapat program yang penyelesaiannya tidak sesuai dengan target waktu yang telah ditentukan. Berikut salah satu petikan dari wawancara dengan informan Kadus Pokoh 2.

“...tadinya kadang ada pekerjaan yang
kurang baik dan belum selesai pada
waktunya..." \#PKH2
kurang baik dan belum selesai pada a..." \#PKH2 
Masalah Sistem Keuangan Anggaran H-1. Menurut bagian Sarpras Desa mekanisme keuangan desa yang berjalan di desa Dlingo selama ini adalah $\mathrm{H}-1$, yakni perencanaan dibuat tahun ini dan akan dieksekusi untuk dua tahun di depan, salah satu yang menjadi pemicu dalam pencapaian kinerja (\#SP). Hal ini berimbas pada lambannya realisasi aspirasi yang sudah tercurahkan dalam rencana pembangunan.

“...Sekarang kan berpatok pada $\mathrm{H}-1$. Artinya perencanaan tahun ini dilaksanakan tahun depan. Jadi berurutan, tidak bisa perencanaan tahun ini dilaksanakan tahun ini. Jadi kita harus merancang kegiatan, misalkan pelaksanaannya di tahun 2017 ya perencanaanya di tahun 2015. Dan yang untuk perencanaan tahun 2016 untuk kegiatan di tahun 2018. Sebenarnya mereka kurang paham yang seperti itu." \#SP

Menurut bagian Sarpras Desa Dlingo, hal ini sempat memicu ketidaksabaran masyarakat desa dan mengira bahwa aspirasi mereka tidak akan dijalankan. Hal itu dikarenakan masyarakat tidak tahu soal mekanisme yang berjalan. Berikut penuturan bagian Sarpras Desa Dlingo:

\begin{abstract}
“... mungkin imbas dari peraturan tingkat pusat daerah 1 dan 2, karena semua usulan dari masyarakat baik desa, kecamatan, kabupaten maupun usulan kelompok itu memang aturannya seperti itu, jadi kita desa terkena imbasnya seperti itu. Padahal inginnya desa, setiap apa yang diusulkan masyarakat tahun depan jalan."\#SP
\end{abstract}

Masalah Semangat Partisipasi dan Aspirasi Versus Prioritas Program. Selain memunculkan kepuasan dan semangat membangun desa, ternyata partisipasi publik juga memicu adanya dampak negatif yang perlu dikontrol, yakni tuntutan yang berlebihan dari masyarakat dalam menyampaikan aspirasinya (\#SP). masyarakat desa tidak sepenuhnya faham mekanisme penjaringan aspirasi. Mereka mengira semua aspirasi harus dipenuhi $(\# \mathrm{PKH} 2)$. Merespon hal tersebut, terdapat masyarakat yang kemudian enggan untuk diajak bekerjasama ketika usulannya tidak disetujui. Meskipun dampak negatif ini tidak begitu berpengaruh besar terhadap pembangunan desa, namun perlu menjadi perhatian Pemdes di tempat lain.

"Hambatan disusun karena keinginan mereka itu tidak sesuai dengan anggaran yang ada, jadi seperti memaksakan diri terhadap usulan yang harus direalisasi."\#SP

“...(ketidakpuasan masyarakat sempat terjadi, pen) karena banyak usulan terutama dari masing-masing dusun itu berbeda, tapi kebijakan dari bapak lurah desa itu mengambil yang mana usulan atau kebijakan mana yang lebih didahulukan dan perlu didanai dulu."\#PKH2

Masalah Tidak Adanya Tindak Lanjut dari Program Pelatihan/Pemberdayaan. Mengacu pada konsep perencanaan stratgik, tujuan dari kegiatan dan program yang diselenggarakan desa adalah bermuara pada pencapaian tujuan (Goal) dan Visi desa (Bastian, 2015). Namun, faktanya yang terjadi di desa adalah, beberapa dari kegiatan yang dilaksanakan masih terbatas pada upaya penghabisan dana desa agar kembali mendapat jumlah yang relative sama di tahun mendatang. Hal itu karena salah satu ukuran kinerja Pemdes adalah realisasi anggaran belanja atau penggunaan uang desa. Hal ini terkait dengan masalah "kejar tayang" program dan kegiatan sebagaimana dijelaskan di bagian sebelumnya. Akhirnya, kegiatan seperti pelatihan dan pemberdayaan ekonomi kreatif, seperti: kuliner, kerajinan dan pariwisata, kerap tidak ada tindak lanjut dari masyarakat (\# LD, SP dan PR). Menurut Lurah Desa, salah satu faktornya adalah masyarakat yang masih belum memiliki inisiatif untuk mengembangkan ilmu baru, dan sudah terlanjur nyaman dengan mata pencaharian yang ada (\#LD).

"saya masih bingung bagaimana cara untuk
menindak lanjuti pelatihan dan pemberda-
yaan yang telah diberikan kepada masya-
rakat. Rata-rata masyarakat banyak yang
tidak menindak lanjutinya. Sehingga prog-
ram dan kegiatan yang telah dilaksanakan
seolah hanya sebatas menghabiskan dana
desa dan tidak ada keberlanjutan tujuan-
nya.... sangat disayangkan."\#LD

Masalah Kurangnya Alokasi Untuk Dana PKK. Menurut Kadus Pakis 1, salah satu kekurangan dari pengelolaan Pemdes terkait keuangan Desa adalah minimnya alokasi dana untuk unit Pembinaan Kesejahteraan keluarga (PKK). Padahal, PKK merupakan unit yang sangat aktif kegiatannya di Desa Dlingo. Hal ini ditunjukkan dengan banyaknya kegiatan yang dikelola PKK, misalnya: arisan sekaligus pemberdayaan ekonomi kreatif ibu-ibu Desa Dlingo, Posyandu, Taman Kanak-kanak (TK), 
dan Pendidikan anak usia dini (Paud) (\#PKS1). Ketika hal ini peneliti konfirmasi kepada Lurah Desa Dlingo, kurangnya dana PKK di benarkan oleh Lurah Desa. Hal itu dikarenakan PKK belum masuk dalam prioritas program dari kegiatan desa saat ini (2016). Disamping itu, belum baiknya penyusunan laporan akuntabilitas PKK dalam penggunaan dana desa juga menjadi alasan kurangnya alokasi dana desa yang diberikan untuk kegiatan PKK itu sendiri (\#LD).

\begin{abstract}
"Alokasi dana yang minim bagi kegiatan ibu-ibu PKK baik secara dusun maupun di desa. Saya pernah dengar kalau desa lain memiliki kas anggaran (PKK, pen) yang besar. Namun disini saya rasakan masih sangat minim sekali. Itu yang membuat Kadus dan ibu-ibu PKK mengeluh."\#PKS1

"Sekarang (beberapa tahun ke belakang dan sampai penelitian ini dilakukan, Desember 2016, pen) PKK memang belum masuk prioritas kita (Program Pemdes, pen). Selain itu permasalahannya adalah pada akuntabilitas pengelolaan dana yang kurang baik. Jadi kita belum bisa berikan jumlah besar itu."\#LD
\end{abstract}

\section{Strategi Menyikapi dan Menyiasati Permasalahan Pengelolaan dan Tata Kelola Desa}

Dari berbagai permasalahan yang terjadi dalam hal pengelolaan program kerja dan keuangan desa, Lurah Desa Dlingo melakukan hal-hal berikut untuk menyikapi dan menyelesaikan masalah yang ada:

Memberikan Pemahaman Mengenai Konsep Pembangunan Desa Secara Persuasif. Temuan yang sangat menarik dari hasil wawancara dengan Lurah dan Bagian Sarpras Desa Dlingo adalah, aspek utama yang mereka lakukan untuk pembangunan desa ternyata bukan perbaikan sistem administrasi atau rumusan rencana strategis, melainkan pembangunan mental manusia (masyarakat) desa supaya termotivasi untuk terlibat dalam pembangunan desa. Lurah Desa menambahkan, Pembangunan Desa Dlingo yang sangat lamban pada periode sebelumnya dikarenakan kelirunya pola pikir masyarakat tentang konsep pembangunan desa, rendahnya partisipasi, dan kurang bangganya masyarakat desa dengan desanya sendiri. Berangkat dari simpulan ini, Lurah Desa Dlingo melakukan tiga hal mendasar sebelum merumuskan rencana stratgik pembangunan desa, yakni: menanamkan semangat berdikari (mandiri), menanamkan bangga dengan desa sendiri dan memberikan pemahaman tentang konsep pembangunan desa.

Menanamkan Semangat Berdikari. Salah satu strategi dalam menyikapi masalah yang dihadapi dalam mengelola desa yang dilakukan pemerintah desa Dlingo adalah menanamkan pola berpikir atau idealism untuk mandiri yang kemudian dijadikan semboyan "Berdikari" (berdiri di atas kaki sendiri) ${ }^{6}$. Hal ini dikarenakan untuk membangun desa diperlukan pola pikir maju dan mandiri dan menghindari faham berpangku tangan pada bantuan orang lain. Hal ini lah yang dilakukan oleh pemerintah Desa Dlingo. Pemerintah desa menilai selama ini masyarakat desa hanya menunggu untuk dibantu oleh pemerintah pusat, privinsi, dan kabupaten. Akhirnya, hal ini mematikan daya kreatifitas masyarakat dan kemauan untuk maju secara mandiri. Selain itu, masayarakat menjadi sangat malas untuk membangun desanya. Karenanya, aspek membangun mental masayarakat ini sangat penting untuk dilakukan sebelum melakukan pembangunan pada desa itu sendiri.

\begin{abstract}
"Saya sampaikan untuk mengelola wilayah sebelum wilayah tersebut terlepas (dikelola orang lain/bukan warga desa Dlingo asli, pen). Mari kita bangun desa yang dikelola secara baik." \#LD
\end{abstract}

Secara mendasar, sebelum renstra disusun dimana di dalamnya terdapat visi dan misi Desa, fihak Pemdes menanamkan terlebih dahulu filosofi yang akan dijalankan desa dalam menggerakkan masyarakat desa (\#LD). Filosofi tersebut, menurut pak Bahrun adalah berpikir melayani (serving) bukan berharap dilayani (served) sebagaimana yang selama ini tertanam dalam benak masyarakat desa. Dari perubahan paradigma ini, fihak Pemdes meyakini bahwa kemajuan desa berawal dari kemajuan cara berfikir masyarakat desanya, yang mana hal itu tidak akan dapat tercapai jika masyarakat masih memiliki pola berpangku tangan, berharap bantuan darian pemerintah kabupaten, provinsi dan pemerintah pusat.

Paradigma melayani ini selanjutnya memunculkan perilaku aktif dalam membangun, sehingga upaya pembangunan desa tidak lagi berfokus pada bagaimana melayani masyarakat, tetapi menyetir (steering) keinginan dan aspirasi masyarakat untuk membangun desanya. Kondisi ini juga memicu masyarakat menjadi lebih kreatif dan inovatif, yang dapat dilihat dari semakin menggeliatnya unit-unit

\footnotetext{
${ }^{6}$ Istilah ini dipopulerkan oleh Presiden pertama RI, Bapak Ir. Soekarno (Allah yarham).
} 
atau organisasi desa yang aktif dalam mengelola potensi desa seperti Pokdarwis (kelompok sadar pariwisata), Pembinaan Kesejahteraan Keluarga (PKK), Karang Taruna, Bina Budaya, Gapoktan (Gabungan Kelompok Tani), Guna Desa, dan Sandigita-IT.

“...ternyata konsep dari orang desa memungkinkan dirubah dari dilayani menjadi melayani... dan itu harus kita fahamkan kepada semua..."\#LD

Menanamkan Bangga dengan Desa. Selain menanamkan semangat berdikari, Lurah Desa Dlingo juga menanamkan bangga desa pada warganya. Hal ini bertujuan agar masyarakat Desa Dlingo lebih merasa memiliki, peduli, dan tanggungjawab untuk mengelola desanya. Sehingga, akhirnya masyarakat akan bekerja keras untuk membangun desanya sendiri, tanpa menunggu belas kasih dari fihak lain.

\begin{abstract}
"yang paling penting adalah bahwa masyarakat kami bangga akan terhadap desannya. Apabila masyarakat bangga terhadap desanya maka pembangunan akan berjalan lancar dan desa akan menjadi maju, sehingga mereka akan bekerja keras. Sekarang yang sudah kami rasakan adalah visi desa sudah sampai di level dusun. Jadi mereka punya impian untuk apa yang harus dilakukan secara visi mereka."\#LD
\end{abstract}

Memberikan Pemahaman Tentang Konsep Pembangunan Desa. Sebagaimana dipaparkan di bagian sebelumnya, salah satu masalah yang muncul dalam pengelolaan desa adalah paradigma masyarakat dan aparatur desa yang masih menilai bahwa pembangunan itu adalah pembangunan fisik saja. Selain itu, perencanaan juga kerap hanya berorientasi pada reaksi dan bukan visi dari desa. Menyikapi hal ini, pemerintah desa Dlingo mengadakan konsolidasi dengan masayarakat dan memberikan pemahaman yang dilakukan secara persuasif (\#LD dan SP).

Beberapa poin yang dilakukan Pemdes Dlingo untuk merubah maindset masyarakatnya agar lebih aktif untuk membangun ini ternyata berbuah hasil positif. Hal itu tidak hanya ditunjukkan dari menggeliatnya uni-unit desa dalam bekerja, berkreasi, dan berinovasi. Tetapi juga di lapangan ditemukan bahwa semangat bekerja keras membangun desa itu tidak didasarkan pada suatu insentif tertentu. Peneliti sendiri tidak menemukan adanya mekanisme insentif yang didesain untuk memicu semangat kerja aparat dan warga desa. partisipasi aparat dan masyarakat ini murni dari adanya perubahan pola pikir dari yang pasif menjadi aktif, dari berpangku menjadi mampu, dari dilayani menjadi melayani.

“...adalah sudut pandang masyarakat masih memandang bahwa pembangunan itu berupa fisik. Jadi untuk pemberdayaan mereka belum ahli dalam membuat rencana... masih sedikit yang memahami bahwa pembangunan itu bukan hanya fisik... Sehingga ini perlu kita arahkan dan fahamkan terlebih dahulu.."\#LD

Membangun sinergi dengan pemerintah Provinsi dan kabupaten serta universitas. Menyikapi berbagai masalah yang dihadapi seperti ketidakfahaman dalam merumuskan renstra, perencanaan dan penganggaran, pelaksanaan program, pengembangan Badan Usaha Milik Desa (BUM Desa), evaluasi dan kontrol, dan pelaporan (akuntabilitas) keuangan dan program (kinerja) desa, dipecahkan Pemdes Dlingo dengan cara berkoordinasi dan bekerjasama dengan fihak Pemkab Bantul dan universitas. Salah satu yang sempat menjadi topik hangat adalah permasalahan dalam pelaporan keuangan (akuntabilitas). Hal itu dikarenakan sampai saat ini belum ada standar baku yang dibuat oleh IAI dalam hal pelaporan dana desa. padahal, dana desa berasal dari tiga sumber, yakni: Pempus, Pemprov, dan Pemkab. Berangkat dari masalah ini, Pemprov DIY dan Pemkab Bantul segera bergerak dengan cara memberikan pendampingan dari profesional yang mengerti praktik akuntansi secara mendalam yang berasal dari pihak universitas dan eks-pendamping PNPM $^{7}$. Tujuannya adalah untuk merumuskan acuan sementara mengenai praktik akuntabilitas pemerintah desa yang harus diikuti (\#LD dan SP). Selain itu, bagian akuntansi desa juga ditangani oleh orang yang memang memiliki dasar pemahaman akuntansi, yakni lulusan Sekolah Menengah Kejuruan (SMK) jurusan akuntansi. meskipun masih level SMA, namun pemerintah desa berupaya untuk menempatkan pegawai di posisi akuntansi sesuai dengan kompetensinya (\#LD).

\footnotetext{
7 PNPM Mandiri Perdesaan -Program Nasional Pemberdayaan Masyarakat Mandiri Perdesaan (PNPM Mandiri Perdesaan atau PNPM-Perdesaan atau Rural PNPM) - merupakan salah satu mekanisme program pemberdayaan masyarakat yang digunakan PNPM Mandiri dalam upaya mempercepat penanggulangan kemiskinan dan perluasan kesempatan kerja di Pedesaan.
} 
“...Jadi kita di BIMTEK oleh pemerintahan provinsi dan pemerintahan kabupaten. Terkait dengan bantuan SDM kami bekerja sama dengan universitas, belajar bagaimana sih menjalankan desa yang baik."\#LD

“... kemarin di awal tahun 2015 itu kita bingung harus pakai acuan yang mana untuk formula pelaporan dan lain sebagainya. Tapi alhamdulillah di awal-awal tahun ini, karena kemarin lewat pemerintahan bisa membuat formula untuk dijadikan sebuah acuan, jadi kami untuk tahun ini sudah ada acuan baku dari aturan itu."\#SP

“Pendamping desa (dari Pemkab Bantul, pen) sekarang itu rata-rata bisa dikatakan pendamping dari eks PNPM, mungkin mereka juga minta rekomendasi atau meminta masukan dari mereka tapi untuk kabupaten lain saya rasa tidak tahu. Karena kita belum ada pelatihan semacam seluruh kabupaten seperti jakarta."\#SP

Menyekolahkan Aparat-Aparat Desa. Sebagaimana dipaparkan di atas, masalah belum mumpuninya kapabilitas SDM Pemdes Dlingo menjadi salah satu masalah utama pengelolaan desa. Sampai sejauh ini, berbagai kendala dapat diatasi dengan melakukan sinergi dengan tenaga ahli dari Pemkab Bantul dan fihak Universitas. Akan tetapi, Lurah Desa tidak ingin selamanya dibantu fihak lain. Lurah Desa Dlingo berkeinginan dan berkeyakinan bahwa mereka dapat mandiri. Karenanya, sebagian dari dana desa dialokasikan untuk beasiswa aparat desa. Bagi aparat yang lulusan SMA ditugaskan untuk melanjutkan studi di di beberapa parguruan tinggi yang ada di kota Yogyakarta.

"Ada tiga orang yang kami sekolahkan, yakni bagian akuntansi dan administrasi. Termasuk saya sendiri (Lurah) juga sedang menempuh studi IImu hokum di (salah satu kampus, pen) di kota Yogyakarta... kita tidak memungkiri kapabilitas kita saat ini masih kurang dan perlu untuk ditingkatkan"\#LD

Pembentukan Forum Lurah Desa Se-Kabupaten Bantul. Dalam rangka mencari ide atau gagasan kreatif dalam tujuan memajukan desa (terkait perumusan perencanaan pemberdayaan potensi desa), Pemdes di lingkup Kabupaten Bantul berinisiatif untuk membentuk paguyuban forum lurah desa se-Kabupaten Bantul. Dengan adanya forum ini, maka pemerintah desa se-kabupaten Bantul memiliki wadah untuk saling bertukar ide dan gagasan kreatif untuk pembangunan desa dan memberdayakan keunggulan/potensi desa.

\begin{abstract}
"Teman-teman lurah (di Bantul, pen) itu membentuk organisasi forum lurah desa disitulah tempat kita berdiskusi biasanya. Masih tentang bagaimana desa membangun sistem keuangan. Jadi kita sudah seperti saudara di kabupaten Bantul untuk lurah-lurah itu."\#LD
\end{abstract}

Kerjasama Pemerintah Desa dan Masyarakat Desa (Gotong Royong). Dalam pelaksanaan program kerja, agar mencapai hasil yang optimal, Desa Dlingo melaksanakannya dengan cara memberikan deligasi kepada Kadus untuk mengeksekusi. Hal ini adalah upaya untuk meningkatkan partisipasi dan pengakuan eksistensi pada organisasi di level Dusun. Upaya ini juga merupakan inovasi di Desa Dlingo yang mana sebelumnya pembangunan lebih tersentral oleh Pemdes. Dengan adanya deligasi, maka terjagalah kearifan lokal dari karakteristik desa di Indonesia pada umumnya, yakni gotongroyong yang berbuah semboyan "Berat sama dipikul, ringan sama dijinjing”. Gotong royong ini sendiri peneliti dapati secara nyata dalam wujud adanya program Merti Desa, Dlingo Expo, Peringatan hari prokalmasi (Tujuh belasan), dan acara kedesaan lainnya.

"Musrembangdus dan berbagai kegiatan
melibatkan orang-orang pedukuhan....
biasanya adalah tokoh masyarakat, pak RT,
tokoh pemuda, kemudian ibu-ibu kader dari
pembina paud dan posyandu, karang
taruna dusun, kelompok kegiatan masya-
rakat. Dari situ kumpul membicarakan
program jangka menengah (yang akan,
pen) dibawa ke desa..."\#PKS1

Koordinasi Mingguan Untuk Mengevaluasi Kinerja Mingguan. Sebagaimana dijelaskan di bagian sebelumnya, masalah yang pernah dihadapi Desa Dlingo adalah adanya Kadus yang tidak mengerjakan tugasnya dengan baik. Di sisi lain, control (pengendalian dan pengawasan) dari desa waktu itu masih lemah. Menyikapi hal itu, pemerintah Desa Dlingo yang baru melakukan koordinasi mingguan yang dilaksanakan di balai desa untuk mendiskusikan rencana kegiatan dan pelaksanaannya. Diskusi berfokus pada perkembangan capaian target, kendala dan hambatan, serta masukan dari berbagai fihak dalam menyikapi kendala dan ham- 
Tabel 2. Matriks Permasalahan dan Strategi Pemecahan Pengelolaan dan Praktik Tata Kelola Pemerintahan Desa Dlingo, Bantul, DIY

\begin{tabular}{|c|c|c|c|c|}
\hline No. & $\begin{array}{c}\text { Kategori } \\
\text { permasalahan }\end{array}$ & $\begin{array}{c}\text { Masalah yang } \\
\text { muncul }\end{array}$ & $\begin{array}{c}\text { Dampak negatif yang } \\
\text { muncul }\end{array}$ & $\begin{array}{c}\text { Strategi } \\
\text { pemecahan }\end{array}$ \\
\hline \multirow{4}{*}{1.} & \multirow{4}{*}{$\begin{array}{l}\text { Permasalahan dalam } \\
\text { perumusan rencana } \\
\text { strategis desa }\end{array}$} & $\begin{array}{l}\text { Masalah teknis } \\
\text { merumuskan renstra }\end{array}$ & $\begin{array}{l}\text { Renstra dibuat secara } \\
\text { tidak benar dan hanya } \\
\text { menjadi "pemanis" atau } \\
\text { "semboyan tanpa } \\
\text { makna" }\end{array}$ & $\begin{array}{ll}\text { 1. } & \text { Sinergi dengan } \\
\text { pemerintah } \\
\text { kabupaten dan } \\
\text { universitas } \\
\text { 2. } & \text { Mendirikan } \\
\text { forum lurah } \\
\text { sekabupaten } \\
\text { bantul } \\
\text { 3. } \\
\text { Menyekolahkan } \\
\text { aparat-aparat desa }\end{array}$ \\
\hline & & $\begin{array}{l}\text { Masalah } \\
\text { pendampingan desa }\end{array}$ & $\begin{array}{l}\text { Desa bingung apa yang } \\
\text { seharusnya dan } \\
\text { sebaiknya dilakukan } \\
\text { dalam mengelola dana } \\
\text { desa }\end{array}$ & $\begin{array}{l}\text { Pendampingan pihak } \\
\text { Pemkab dan } \\
\text { Universitas }\end{array}$ \\
\hline & & $\begin{array}{l}\text { Masalah praktik } \\
\text { kejar tayang }\end{array}$ & $\begin{array}{l}\text { Hanya terfokus pada } \\
\text { akuntabilitas keuangan } \\
\text { dan ketaatan hukum, } \\
\text { sementara renstra desa } \\
\text { untuk mewujudkan cita- } \\
\text { cita kemandirian desa } \\
\text { terabaikan }\end{array}$ & $\begin{array}{l}\text { Pendampingan fihak } \\
\text { Pemkab dan } \\
\text { Universitas }\end{array}$ \\
\hline & & $\begin{array}{l}\text { Masalah paradigma } \\
\text { masyarakat bahwa } \\
\text { pembangunan } \\
\text { adalah fisik desa }\end{array}$ & $\begin{array}{l}\text { Program yang diusulkan } \\
\text { hanya pembangunan } \\
\text { fisik, bukan manusia }\end{array}$ & $\begin{array}{l}\text { Memberikan } \\
\text { pemahaman secara } \\
\text { persuasif mengenai } \\
\text { konsep pembangunan } \\
\text { desa }\end{array}$ \\
\hline 2. & $\begin{array}{l}\text { Permasalahan dalam } \\
\text { pelaporan keuangan dan } \\
\text { kinerja desa }\end{array}$ & $\begin{array}{l}\text { Benturan peraturan } \\
\text { dan belum adanya } \\
\text { standar pelaporan }\end{array}$ & $\begin{array}{ll}\text { 1. } & \text { Kebingungan } \\
\text { Pemdes dalam } \\
\text { menyusun laporan } \\
\text { keuangan. } \\
\text { 2. } \\
\text { Laporan keuangan } \\
\text { tidak sesuai standar } \\
\text { karaktateristik } \\
\text { kualitatif dan tidak } \\
\text { tepat waktu }\end{array}$ & 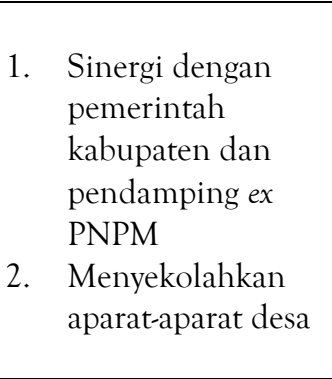 \\
\hline \multirow[t]{2}{*}{3.} & \multirow[t]{2}{*}{$\begin{array}{l}\text { Permasalahan } \\
\text { pencapaian kinerja desa }\end{array}$} & $\begin{array}{l}\text { Kurangnya kontrol } \\
\text { atas program kerja } \\
\text { yang belum berjalan } \\
\text { baik } \\
\text { Masalah sistem } \\
\text { keuangan anggaran } \\
\text { H-1 }\end{array}$ & $\begin{array}{l}\text { Program kerja yang } \\
\text { dilaksanakan kurang } \\
\text { optimal }\end{array}$ & $\begin{array}{l}\text { Koordinasi rutin } \\
\text { mingguan untuk } \\
\text { mengevaluasi kinerja }\end{array}$ \\
\hline & & $\begin{array}{l}\text { Masalah semangat } \\
\text { partisipasi dan } \\
\text { aspirasi versus } \\
\text { prioritas program }\end{array}$ & $\begin{array}{l}\text { Program kerja yang } \\
\text { dilaksanakan kurang } \\
\text { optimal }\end{array}$ & $\begin{array}{l}\text { Ajakan secara persuasif } \\
\text { dari Pemdes kepada } \\
\text { masyarakat desa untuk } \\
\text { beerjasama (gotong } \\
\text { royong) }\end{array}$ \\
\hline
\end{tabular}


Tabel 2. Matriks Permasalahan dan Strategi Pemecahan Pengelolaan dan Praktik Tata Kelola Pemerintahan Desa Dlingo, Bantul, DIY (Lanjutan...)

\begin{tabular}{|c|c|c|c|c|}
\hline No. & $\begin{array}{c}\text { Kategori } \\
\text { permasalahan }\end{array}$ & $\begin{array}{c}\text { Masalah yang } \\
\text { muncul }\end{array}$ & $\begin{array}{c}\text { Dampak negatif yang } \\
\text { muncul }\end{array}$ & $\begin{array}{c}\text { Strategi } \\
\text { pemecahan }\end{array}$ \\
\hline \multirow[t]{2}{*}{3.} & \multirow[t]{2}{*}{$\begin{array}{l}\text { Permasalahan } \\
\text { pencapaian kinerja desa }\end{array}$} & $\begin{array}{l}\text { Masalah tidak } \\
\text { adanya tindak lanjut } \\
\text { dari program } \\
\text { pelatihan/ } \\
\text { pemberdayaan }\end{array}$ & $\begin{array}{l}\text { Kegiatan hanya bersifat } \\
\text { penghabisan uang desa } \\
\text { tanpa adanya target yang } \\
\text { hendak dicapai }\end{array}$ & Belum ada solusi \\
\hline & & $\begin{array}{l}\text { Masalah kurangnya } \\
\text { alokasi untuk dana } \\
\text { PKK }\end{array}$ & $\begin{array}{l}\text { Kegiatan pkk terkendala } \\
\text { dana }\end{array}$ & $\begin{array}{l}\text { Desa merencanakan } \\
\text { pelatihan terkait } \\
\text { penyusunan laporan } \\
\text { akuntabilitas dana PKK }\end{array}$ \\
\hline
\end{tabular}

batan yang terjadi (\#LD, SP, PKS1, PKS2, PKH2, KBS1, KBS2).

“... setiap hari jum'at diadakan koordinasi dari lurah desa. Jadi setiap masukan dari setiap dusun itu pak lurah tahu."\#PKH2

\section{Permasalahan yang Belum Terpecahkan}

Dari berbagai permasalahan yang dihadapi desa Dlingo, sebagian besar dapat dipecahkan dengan strategi sebagaimana dijelaskan di atas. Namun, terdapat pula permasalahan yang belum ditangani dan ditemukan pemecahannya, yakni (1) masalah tidak adanya tindak lanjut dari program pelatihan/ pemberdayaan, (2) masalah sistem keuangan anggaran $\mathrm{H}-1$ dan (3) upaya untuk memberikan pelatihan akuntabilitas bagi PKK agar ada rasa aman dari Lurah Desa ketika mengalokasikan dana yang lebih besar untuk kegiatan unit tersebut. Untuk kasus alokasi dana PKK, hal ini penting untuk diperhatikan mengingat bagi Pemdes Dlingo, unit PKK merupakan unit yang memiliki kegiatan yang banyak dan berdampak positif bagi masyarakat, seperti: arisan sekaligus pemberdayaan ekonomi kreatif ibu-ibu Desa Dlingo, Posyandu, Taman Kanak-kanak (TK), dan Pendidikan anak usia dini (Paud) (\#PKS1). Namun demikian, dari followup peneliti kepada Pemdes Dlingo terkait opini Kadus Pakis 1 ini, Pemdes Dlingo sudah merencanakan untuk masa mendatang agar PKK diberikan pelatihan pelaporan akuntabilitas menggunakan software agar lebih mudah, serta optimalisasi pemberdayaan PKK menjadi lebih baik oleh Pemdes Dlingo adalah suatu niat yang baik dan diharapkan dapat direalisasikan.

Berdasarkan berbagai macam strategi yang dijalankan oleh Pemdes Dlingo dalam menyikapi permasalahan yang muncul, maka dapat disimpulkan dalam bentuk matriks sederhana sebagaimana yang disajikan pada Tabel 2 .

\section{SIMPULAN}

Penelitian ini bertujuan untuk menginvestigasi permasalahan yang dihadapi desa Dlingo dalam mengelola (management) dan menjalankan praktik tata kelola (governance) desa dan pula strategi yang dijalankan dalam menyikapi permasalahan yang muncul. Dari hasil studi ditemukan bahwa permasalahan yang terjadi dalam pelaksanaan pemerintahan desa dapat dibagi menjadi tiga sub utama, yakni: (1) masalah perumusan rencana strategis, (2) masalah pelaporan keuangan dan kinerja, dan (3) masalah pencapaian kinerja desa. Dalam rangka menyikapi permasalahan yang terjadi terkait perencanaan strategis dan pelaporan keuangan dan kinerja desa, pemerintah desa melakukan sinergi dengan Pemkab, Pemprov, dan fihak universitas untuk mendapatkan pendampingan dan pembinaan. Selain itu, Pemdes Dlingo juga aktif menyekolahkan beberapa pegawainya. Dalam rangka meningkatkan kinerja desa guna mencapai visi dan misi yang berujung pada kemandirian desa Dlingo, Pemdesa Dlingo melakukan pendekatan persuasif untuk memotivasi masyarakat Desa supaya dapat berfikir mandiri dan bangga dengan desanya sendiri, sehingga memicu motivasi untuk terlibat aktif dalam membangun desa.

Implikasi dari temuan penelitian ini yakni penting bagi Pemdes untuk merubah pola pikir masyarakat desa sebelum pembangunan desa dijalankan. Hal ini bertujuan agar pembangunan desa tidak dijalankan berdasarkan keterpaksaan karena menerima dana desa, akan tetapi berdasarkan kesadaran untuk menjadikan desa menjadi mandiri. Selain itu, penting bagi desa untuk mendelgasikan pegawainya untuk menempuh studi lanjut, juga senantiasa membangun sinergi kepada level pemerintah yang lebih tinggi di atasnya (Pemkab dan Pemprov), lembaga universitas dan antar Desa itu sendiri dalam upaya berbagi ilmu pengetahuan dan teknologi dalam rangka meno- 
pang Pemdes untuk mengatasi berbagai permasalahan pengelolaan dan praktik tata kelola desa. Terakhir, dalam rangka peningkatan kinerja desa, maka kearifan lokal rakyat Indonesia, yakni budaya gotong royong harus senantiasa digalakan.

Penelitian ini memiliki keterbatasan yang disebabkan oleh pendekatan yang digunakan adalah studi kasus pada satu obyek saja. Karenanya, hasil penelitian ini tidak dapat digeneralisir secara luas untuk konteks seluruh Pemdes di Indonesia. Karena itu maka penelitian selanjutnya sangat disarankan untuk membuat penelitian dengan desain berbeda dalam rangka menemukan hasil temuan yang bersifat umum, misalnya dengan pendekatan survey atau observasi data sekunder. Meskipun terdapat keterbatsan ini, namun demikian hasil ini tetap memiliki kebermanfaatan sebagai informasi yang berguna dalam menyikapi permasalahan pengelolaan desa jika ternyata terdapat masalah serupa yang ada di desa lain, sebagaimana yang dipaparkan pada temuan-temuan penelitian ini.

Keterbatasan lain dari penelitian ini adalah temuan yang relatif masih menyampaikan kasus yang bersifat umum. Karenanya, investigasi lebih dalam perlu dilakukan untuk menyajikan temuan yang lebih detail. Sebagai contoh, pada temuan ini tidak disajikan bagaimana secara detail pelaporan keuangan disusun oleh desa dalam rangka menyikapi adanya variasi standar pelaporan yang dituntut pemberi sumber dana (Pempus, Pemprov, dan Pemkab). Sementara itu, acuan atau standar akuntansi pelaporan keuangan yang secara resmi diterbitkan oleh IAI atau Pemerintah belum diadakan. Dari temuan ini, maka investigasi dan isu pelaporan keuangan desa menarik untuk diteliti di masa mendatang, khususnya terkait rumusan pelaporan keuangan desa yang sebaiknya disusun dan dijadikan acuan resmi pelaporan keuangan Pemerintah desa.

\section{UCAPAN TERIMA KASIH}

Penulis mengucapkan terima kasih yang sebesar-besarnya kepada pihak Universitas Muhammadiyah Yogyakarta yang telah menjadi sponsor utama pemberi bantuan dana dari penelitian ini dalam skema hibah penelitian kemitraan. Selain itu penulis juga mengucapkan terima kasih kepada reviewer yang telah memberikan masukan dan beberapa catatan untuk perbaikan paper ini.

\section{DAFTAR PUSTAKA}

Amirullah, M. A., Ulum, I. \& Prasetyo, A. (2016). Analysis of Financial Management Based on Minister Home Affairs Regulation 113 of 2014 (Case study in Brumbungan Kidul Village, Maron Sub-district, Probolinggo Regency). Proceedings of Internastional Conference on Accounting and Finance, Universitas Muhammadiyah Yogyakarta, Maret 2016.

Bastian, I. (2015). Akuntansi Kecamatan dan Desa. Jakarta: Penerbit Erlangga.

Braun, V. \& V. Clarke. (2006). Using Thematic Analysis in Psychology. Qualitative Research in Psychology, 3, 77-101

Cavalluzzo, K. S., \& Ittner, C. D. (2004). Implementing performance measurement innovations: evidence from government. Accounting, Organizations and Society, 29(3), 243. 267.

Creswell, J. W. (2010). Research Design: Qualitative, Quantitative and Mixed Methods Approaches. California: Sage Publication.

Gudono. (2014). Teori Organisasi. Yogyakarta: BPFE Yogyakarta.

Jones, R., \& Pendlebury, M. (2015). Public Sector Accounting. Pearson Education.

Mardiasmo. (2015). Akuntansi Sektor Publik. Yogyakarta: Penerbit ANDI.

Riyanto, T. (2015). Akuntabilitas Finansial Dalam Pengelolaan Alokasi Dana Desa (ADD) Di Kantor Desa Perangat Selatan Kecamatan Marangkayu Kabupaten Kutai Kartanegara. eJournal Administrasi Negara, 3(1), 119-130.

Sofyani, H., \& Akbar, R. (2013). Hubungan Faktor Internal Institusi dan Implementasi Sistem Akuntabilitas Kinerja Instansi Pemerintah (SAKIP) di Pemerintah Daerah. Jurnal Akuntansi dan Keuangan Indonesia, 10(2), 184205.

Sofyani, H. \& Akbar, R. (2015). Hubungan Karakteristik Pegawai Pemerintah Daerah dan Implementasi Sistem Pengukuran Kinerja: Perspektif Ismorfisma Institusional. Jurnal Akuntansi \& Auditing Indonesia, 19(2), 153. 173.

Subroto, A. (2009). Accountability of Village Fund Allocation Management (case study in Tlogomulyo Sub-District, Temanggung Regency). Master Theses, Universitas Diponegoro.

Ulum, I., \& Sofyani, H. (2016). Akuntansi (Sektor) Publik. Yogyakarta: Aditya Media Publishing.

Utomo, S. J. (2015). Implementasi Kebijakan Anggaran Pendapatan dan Belanja Desa (APBDes) Untuk Meningkatkan Pembangunan Desa (Studi Kasus 
di Desa Bandung Kecamatan Gedeg Kabupaten Mojokerto). Media Trend, 10(1), 27-46.

Undang-Undang No. 6 tahun 2014 Tentang Desa

Wijaya, A. H. C. \& Akbar, R. 2013. The Influence of Information, Organizational Objective and Targets, and External Pressure toward The Adoption of Performance Measurement System in Public Sector. Journal of Indonesian Economy and Business, 28, 62-83. 